\title{
Emergency Decapitation of Calf in Hf Cows
}

\author{
Pridhvidhar Reddy YV *, Siva Kumar RV and Sudhakara Reddy B \\ Department of Veterinary Clinical Complex, Sri Venkateswara Veterinary University, India
}

Submission: February 10, 2017; Published: March 23, 2017

*Corresponding author: Pridhvidhar Reddy YV, Department of Veterinary Clinical Complex, Sri Venkateswara Veterinary University, Proddatur, Andhra Pradesh-516360, India, Email: prithvi524@gmail.com

\begin{abstract}
The present communication explicates the dystocia in three cross bred heifers owing to malposture and relatively large sized fetus. The malposture was instigated by severe left lateral deviation of head and neck of the fetus. Emergency decapitation was done in all the cases and it was successfully handled without any post-operative complications.
\end{abstract}

Keywords: Fetal dystocia; Decapitation; Cows

\section{Introduction}

Dystocia is defined as delayed or difficult calving, sometimes requiring significant human assistance. The causes of dystocia have been described from a number perspectives based on a analysis of large number of calving records in dairy and beef cows [1]. Fetopelvic disproportion is the foremost cause of dystocia in cross bred heifers [2]. It requires caesarean section for the fetal delivery by virtue of its inability to deliver the fetus through the narrow birth canal of normal size [3]. The present communication envisage the correction and management of fetal malposture characterized by left lateral deviation of head and neck which was subsequently rectified by manual repulsion in conjunction with emergence decapitation without any postoperative complications at field level.

\section{Case History and Observations}

Three cross bred heifers were presented to the clinic with a history of first water bag rupture and labor pain for about 18$24 \mathrm{hrs}$. It was also reported that the many futile attempts were applied by local para veterinarians. On clinical examination all the cows appeared alert and active with elevated rectal temperature, pulse and respiratory rate. The fetal forelimbs were presented outside the birth canal and per-vaginal examination revealed severe left lateral deviation of head and neck were felt. Head was totally unapproachable by manual vaginal examination and the fetus was diagnosed to be dead in all the cases.Discussion and Treatment

The pelvic space was insufficient to correct the mal position; hence it was decided to perform repulsion of fetal forelimbs back into the birth canal under epidural anesthesia which was achieved by $2 \%$ lignocaine and through lubrication of birth canal by warm Carboxy methyl cellulose. The fetal head was brought into the pelvic inlet by grasping of muzzle manually followed by extension of fore limbs. Owing to the insufficient space in the pelvis to go for traction; amputation of head was performed by blade engaging the head outside the vulva and an incision is made on skin near at lanto occipital joint followed by muscles and finally head is twisted to remove head. The fetus is then repelled and abnormal posture of limbs is corrected by mutation. The traction was applied on neck and two front legs and dystocia was relieved (Figure $1 \& 2$ ). Following delivery the animals were treated with Ceftriaxone inj (3gms IMx5 days), Intalyte $(500 \mathrm{ml}$, IVX3days), calcium borogluconate $(450 \mathrm{ml}$, IV X one day), and Meloxicam inj (15ml, IMX3days) and an herbal uterotonic was prescribed.

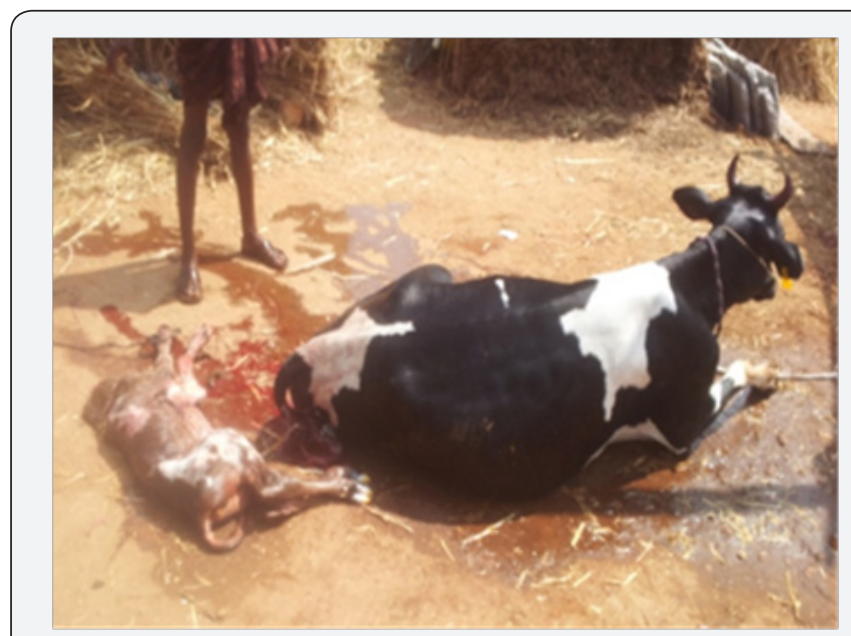

Figure 1: Cow with Fetotomy calf. 


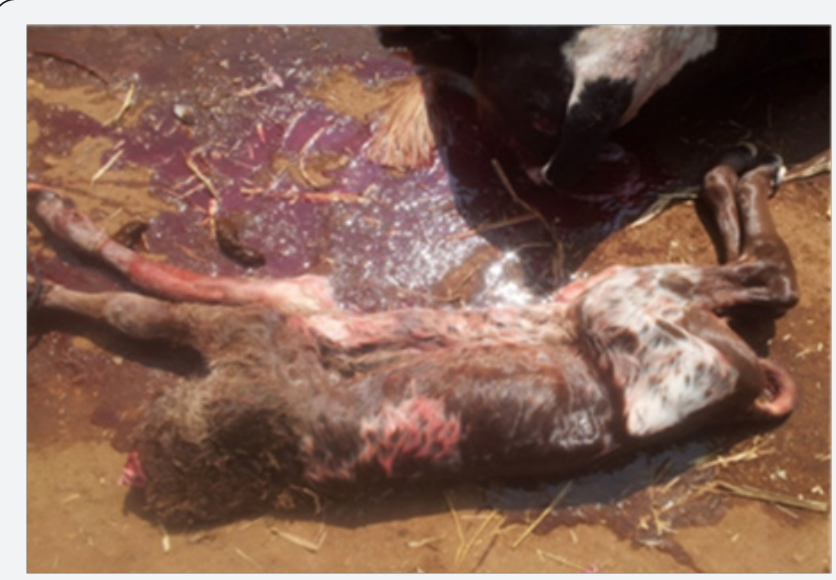

Figure 2: Fetotomy calf.

Fetal dystocia is common in cows \& buffalos. Fetal oversize is common in heifers, cows of beef cattle breeds, prolonged gestations, increased calf birth weight and perinatal fetal death with resultant emphysema. Advancement in breeding programmes and domestication paved entity for array of disorders for instance, crossbreeding has high eventually dystocia in cross bred cows than purebreds which have ensued the cows to produce calves that are relatively larger in size compared to their dams than occurs with most other mammals [4]. Fetotomy in cows was also performed by Ontari et al. [5], Rao \& Murthy [6]. Studies analyzing calving difficulties in cattle have critically addressed the importance of calf birth weight, sex of calf and fetal death as important fetal causes of fetal dystocia in cattle. However, in a clinical setting the fetal size relative to the birth canal and fetal size mal dispositions appear to be of prime importance as they decide the course of action to be taken by clinician. The frequency of difficult in calving was $15.2 \%$ in HF heifers and only $2.2 \%$ in jersey heifers [7]. There exists high correlation between pelvic size and calving ease in HF cows than compared to other breeds, Friesian cattle has smallest pelvic area at first calving [8]. The method adopted to correct the dystocia and fetal survival depends upon the time of presentation of animal after onset of second stage of labour and expertise available [9].

\section{References}

1. Lombard JE, Gary FB, Tomilson SM, Garber LP (2007) Impacts of dystocia on health and survival of dairy calves. Journal Dairy Science 90(4): 1751-1760.

2. Fourichon C, Seegers H, Mahler X (2000) Effect of dystocia on reproduction in the dairy cow: a meta-analysis. Theriogenology 53(9): 1729-1759.

3. Purohit GN, Kumar P, Solanki K, Shekher C, Yadav SP (2012) Perspectives of fetal dystocia in cattle and buffalo. Veterinary Science Development 2(1): e8.

4. Noakes D, Parkinson TJ, England GCW (2001) Dystocia and other disorders associated with parturition. ( $8^{\text {th }}$ edn), Arthur's Veterinary Reproduction and Obstetrics Saunders, UK, pp. 205-217.

5. Otonari S, Nakai M, Yamaguchi R, Hagio M, Nasu T (1993) Five cases of cranial duplication in a calf. J Vet Med Sci 55(3): 493-495.

6. Rao MN, Murthy TSN (1994) A case report of bovine conjoined twin Indian Veterinary Journal 71: 1242.

7. Nogalski Z, Mordas W (2012) Pelvic parameters in Holstein-Friesian and Jersey heifers in relation to their calving. Pak Vet J 32(4): 507-510.

8. Ramin AG, Daniel RCW, Fenwick DC, Verrall RG (1995) Pelvic parameters, growth rate, puberty, and their relationships in young dairy heifers. Reprod Dom Anim 30: 117-123.

9. Zaborski D, Grzesiak W, Szatkowska I, Dybus A, Muszynska M, et al. (2009) Factors affecting dystocia in cattle. Reproduction Domestic Animals 44(3): 540-551.

\section{Your next submission with Juniper Publishers will reach you the below assets}

- Quality Editorial service

- Swift Peer Review

- Reprints availability

- E-prints Service

- Manuscript Podcast for convenient understanding

- Global attainment for your research

- Manuscript accessibility in different formats ( Pdf, E-pub, Full Text, Audio)

- Unceasing customer service

Track the below URL for one-step submission https://juniperpublishers.com/online-submission.php 